\title{
In vitro anticancer activity of microbial isolates from diverse habitats
}

\author{
Angel TreasaThomas ${ }^{1}$, Josyula Venkata Rao ${ }^{1, *}$, Volety Mallikarjuna Subrahmanyam ${ }^{1}$, \\ Hariharapura Raghu Chandrashekhar ${ }^{1}$, Naseer Maliyakkal', Tukaram Kedar Kisan ${ }^{1}$, Alex Joseph ${ }^{2}$, \\ Nayanabhirama Udupa ${ }^{3}$
}

\author{
${ }^{1}$ Department of Pharmaceutical Biotechnology, ${ }^{2}$ Department of Pharmaceutical Chemistry, ${ }^{3}$ Department of Pharmacy \\ Management, Manipal College of Pharmaceutical Sciences, Manipal University, India
}

\begin{abstract}
Extracts from natural products, especially microorganisms, have served as a valuable source of diverse molecules in many drug discovery efforts and led to the discovery of several important drugs. Identification of microbial strains having promising biological activities and purifying the bio-molecules responsible for the activities, have led to the discovery of many bioactive molecules. Extracellular, as well as intracellular, extracts of the metabolites of thirty-six bacterial and twenty-four fungal isolates, grown under unusual conditions such as high temperature, high salt and low sugar concentrations, were in vitro tested for their cytotoxic potential on various cancer cell lines. The extracts were screened on HeLa and MCF-7 cell lines to study the cytotoxic potential. Nuclear staining and flow cytometric studies were carried out to assess the potential of the extracts in arresting the cell cycle. The crude ethylacetate extract of isolate F-21 showed promising results by MTT assay with $\mathrm{IC}_{50}$ as low as $20.37 \pm 0.36 \mu \mathrm{g} / \mathrm{mL}$ on HeLa, and $44.75 \pm 0.81 \mu \mathrm{g} / \mathrm{mL}$ on MCF-7 cells, comparable with Cisplatin. The isolate F-21 was identified as Aspergillus sp. Promising results were also obtained with B-2C and B-4E strains. Morphological studies, biochemical tests and preliminary chemical investigation of the extracts were also carried out.
\end{abstract}

Uniterms: Anticancer. Cytotoxicity. Flow cytometry. Microbial extracts. MTT assay.

Extratos de produtos naturais, especialmente de microrganismos, constituíram-se em fonte valiosa de diversas moléculas em muitas descobertas de fármacos e levaram à descoberta de fármacos importantes. A identificação de espécies microbianas que apresentam atividade biológica e a purificação de biomoléculas responsáveis pelas atividades levou à descoberta de muitas moléculas bioativas. Extratos extracelulares tanto quanto intracelulares de metabólitos de 36 isolados de bactérias e 24 isolados de fungos, que cresceram sob condições não usuais, como alta temperatura, alta concentração de sal e baixa concentração de açúcar, foram testados in vitro quanto ao seu potencial citotóxico em várias linhagens de câncer. Os extratos foram ensaiados em células HeLa e MCF-7 para o estudo do potencial citotóxico. A coloração nuclear e os estudos de citometria de fluxo foram realizados para avaliar o potencial dos extratos em bloquear o ciclo celular. $\mathrm{O}$ extrato bruto em acetato de etila do isolado F-21 mostrou resultados promissores

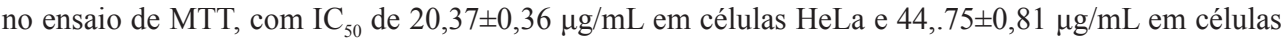
MCF-7, comparativamente à cisplatina. $\mathrm{O}$ isolado F-21 foi identificado como Aspergillus sp. Resultados promissores foram obtidos com cepas B-2C e B-4E. Realizaram-se, também, estudos morfológicos, testes bioquímicos e investigação química preliminar dos extratos.

Unitermos: Anticâncer. Citotoxicidade. Citometria de fluxo. Extratos microbianos. Ensaios MTT.

*Correspondence: Dr. J. Venkata Rao. Department of Pharmaceutical Biotechnology, Manipal College of Pharmaceutical Sciences, Manipal University. Manipal-576104, India. E mail: rao.josyula@gmail.com 


\section{INTRODUCTION}

From time immemorial, natural products have played an important role in treating and preventing human diseases. Natural products with medicinal value have come from various sources viz., terrestrial plants, terrestrial microorganisms, marine organisms, and terrestrial vertebrates and invertebrates (Newman et al., 2000, 2002). The microbial extracts have served as a valuable source of diverse molecules in many drug discovery efforts and led to the isolation of several important drugs. Microbial diversity contributes as an infinite resource for novel drug discovery. Recent estimates suggest that to date, we only know approximately $5 \%$ of the total species of fungi and maybe as little as $0.1 \%$ of bacteria. And among the those already described, only a small fraction has been examined for their biological activity profile (Clardy, 2007). Pharmacological evaluation of microbial extracts is an essential aspect of the drug discovery process. Developments in the area of in vitro techniques have substantially transformed this facet of natural product chemistry (Rahman et al., 2001). The microbial secondary metabolites can be brought into use in three different ways: the bioactive molecule can be produced directly by fermentation; or the fermentation product can be used as starting material for subsequent chemical modification (derivatization); or thirdly the molecules can be used as lead compounds for chemical synthesis. However, the chemical composition of bioactive compounds of microbial origin are often highly complex, including stereochemical diversities which in many instances will make chemical synthesis difficult as far as economy is concerned (Lene, 1996). Organic compounds from aqua to terrestrial microorganisms have extensive past and present use in the treatment of many diseases and serve as compounds of interest both in their natural form and as templates for synthetic modification. These compounds provided important contributions to the discovery of antibacterial agents (penicillins, cephalosporins, aminoglycosides, tetracyclines, and polyketides), immunosuppressive agents (cyclosporins and rapamycin), cholesterol-lowering agents (lovastatin and mevastatin), antihelmintic agents (ivermectin), antidiabetic agent (acarbose) and anti cancer agents (eg, pentostatin, peplomycin, and epirubicin) (Butler, 2005; Sneader, 2005).

The search for biologically active small molecules produced by soil microbes is conceptually simple. Soil samples are collected and microbes are cultured on agar plates containing the necessary nutrients. Identification of microbial strains having promising biological activities and purifying the bio-molecules responsible for the activities has led to the discovery of many bioactive molecules (Friedler, 2004; Marianna et al., 1995). Against this background, in the present study, we isolated microbes from various habitats and tested their extracts for a range of biological activities, in order to obtain valuable compounds for the treatment of diseases, especially cancer.

\section{MATERIALS AND METHODS}

All the culture media were purchased from HiMedia Laboratories, Mumbai, Fetal Bovine Serum, Dulbecco's Modified Eagle's Medium (DMEM), MTT, Hoechst 33342, Propidium Iodide and Trypsin were purchased from Sigma Aldrich, Germany. Cell Lines such as MCF -7 (Human-Breast cancer-epithelial) was purchased from the National Centre for Cell Science, Pune, India and HeLa (Human-Cervical Cancer-epithelial) was obtained from the Indian Institute of Science Bangalore, India.

Sixty different microbial isolates, deposited at the Department of Pharmaceutical Biotechnology, MCOPS, Manipal, were used for the study. Of these, 36 were bacterial (Coded as B) and 24 were fungal isolates (Coded as F), isolated under unusual conditions such as high temperature, high Sodium Chloride and low glucose concentrations (Angel et al., 2009). Extracellular as well as intracellular extracts of the metabolites of these isolates were prepared as discussed below:

\section{Inoculum development and production of metabolites}

Nutrient broth was used for bacterial cultures whereas fungal broth containing $1 \%$ peptone and $2 \%$ dextrose was used for fungal cultures. In the case of bacterial cultures, $5 \mathrm{~mL}$ of inocula were developed in Nutrient broth by incubating at $37^{\circ} \mathrm{C}$ for $24 \mathrm{~h}$. Similarly, fungal inocula were developed in fungal broth by incubating at $27^{\circ} \mathrm{C}$ for $72-96 \mathrm{~h}$. These were then used to inoculate the production media and incubated at $37^{\circ} \mathrm{C}$ for 24 to $48 \mathrm{~h}$ in case of bacterial cultures, and $27^{\circ} \mathrm{C}$ for $4-5$ days in case of fungal cultures, at $150 \mathrm{rpm}$ on a rotary shaker incubator. These broths were used for the extraction of extracellular and intracellular metabolites.

\section{Extraction of bioactive principles}

The culture broth was centrifuged at $3000 \mathrm{rpm}$ for 15 min to obtain a clear supernatant. Extracellular components were extracted successively with solvents such as Petroleum ether (P), Ethyl acetate (E) and chloroform (C) for extracellular extracts, followed by vacuum evaporation of these extracts to obtain the dry extracts. 
The cell sediment obtained on centrifugation of the inocula is used to prepare the intracellular extract. The cells were redispersed in $5 \mathrm{~mL}$ of methanol, probe sonicated to release the intracellular components and then centrifuged. The methanol in the supernatant was then evaporated off and the dried intracellular extract (M) was obtained on freeze drying (Kim et al., 2004).

\section{Sample preparation for biological studies}

The extracellular and intracellular crude extracts were dissolved in $1 \mathrm{~mL}$ dimethylsulphoxide (DMSO) and transferred to sterile vials. These samples were stored at room temperature and protected from light. For cytotoxicity studies, the extract volume was fixed in such a way that final concentration of DMSO did not exceed $0.1 \%$.

\section{In vitro anticancer activity studies}

The extracellular and intracellular extracts prepared were subjected to in vitro cytotoxicity screening on HeLa cells by the MTT (3-[4, 5-dimethylthiazol-2-yl]-2, 5-diphenyltetrazolium bromide) method. The most active extracts were further screened on MCF-7 cells by MTT assay. Based on the results of in vitro anticancer studies of all extracellular and intracellular extracts, two highly active extracts were selected for Hoechst 33342 staining and cell cycle analysis to study the compound mediated apoptosis on HeLa cells.

\section{Determination of mitochondrial synthesis by micro culture tetrazolium (MTT) assay}

The monolayer cell culture was trypsinized using TPVG (Trypsin - Versine - Glucose) and the cell count was adjusted to $1.0 \times 10^{5}$ cells $/ \mathrm{mL}$ in the medium containing $10 \%$ Fetal bovine serum. Each well of the 96 well plates was seeded with $10^{5}$ cells. After $24 \mathrm{~h}$, when a partial monolayer was formed, the supernatant was flicked off and $100 \mu \mathrm{L}$ of $(1000$ to $31.25 \mu \mathrm{g} / \mathrm{mL})$ test extracts were added to the cells in microtiter plates. The plates were incubated at $37{ }^{\circ} \mathrm{C}$ for $72 \mathrm{~h}$ in a $5 \% \mathrm{CO}_{2}$ atmosphere. After $72 \mathrm{~h}$, the drug solutions in the wells were discarded and $50 \mu \mathrm{L}$ of MTT (MTT: prepared in Hank's Balanced Salt Solution without phenol red [(HBSS-PR), $2 \mathrm{mg} / \mathrm{mL}$, Sigma Chemicals] was added to each well. The plates were gently shaken and incubated for $3 \mathrm{~h}$, at $37^{\circ} \mathrm{C}$, in $5 \%$ $\mathrm{CO}_{2}$ atmosphere. The supernatant was removed, $50 \mu \mathrm{L}$ of 1- propanol was added, and the plates were gently shaken to solubilize the formed formazan. The absorbance was measured using a Microplate reader (ELISA Reader,
Biotek) at $540 \mathrm{~nm}$ (Jeffrey et al., 1998; Rubinstein et al., 1990; Eisenbrand et al., 2002).

\section{Hoechst 33342 staining for scoring apoptosis}

HeLa cell line was maintained in DMEM with $10 \%$ fetal bovine serum at $37{ }^{\circ} \mathrm{C}$ in a $\mathrm{CO}_{2}$ incubator at $5 \%$ $\mathrm{CO}_{2}$ atmosphere. The compounds to be screened for their potential apoptotic activity were added to the cells in log phase at a concentration of their $\mathrm{IC}_{50}$ value, determined from cytotoxicity assay. Cells were treated with the compounds under the above-mentioned cell culture conditions for a period of $48 \mathrm{~h}$. Cells were monitored under a phase contrast microscope at an interval of $12 \mathrm{~h}$ till the end of the treatment to evaluate compound mediated cell death.

At the end of treatment, cell culture medium was removed and cells were washed with $1 \mathrm{X}$ concentration of phosphate buffer saline (PBS, $\mathrm{pH} 7.4$ ). $0.5 \mathrm{~mL}$ of trypsinEDTA solution was added to the cells and incubated at $37^{\circ} \mathrm{C}$ and $5 \% \mathrm{CO}_{2}$ for $3 \mathrm{~min}$. After trypsinisation, cells were rounded and detached from the cell culture plate. To this, $5 \mathrm{~mL}$ of DMEM with $10 \%$ fetal bovine serum was added, and the cell suspension was centrifuged at $1200 \mathrm{rpm}$ for $4 \mathrm{~min}$ at room temperature. The pellet was resuspended in the media and cells were counted. Cell count was adjusted to 50,000 cells $/ \mathrm{mL}$. Cells were washed twice with PBS and stained with Hoechst $33342(2 \mu \mathrm{g} / \mathrm{mL}$ in PBS) for $10 \mathrm{~min}$ at $37^{\circ} \mathrm{C}$. At the end of staining, cells were centrifuged at $1200 \mathrm{rpm}$ for $4 \mathrm{~min}$ at $4{ }^{\circ} \mathrm{C}$. The pellet was washed with PBS twice and spotted on a cover slip. This was observed under fluorescent microscope to spot normal cells as well as cells showing apoptotic morphology. Doxorubicin was used as a positive control for apoptosis in the study. DMSO was used as the vehicle control (Yao et al., 2009).

\section{Cell cycle analysis by flow cytometry}

Cell cycle analysis was performed by flow cytometric measurements of the DNA content of the cells based on propidium iodide staining. For cell cycle analysis, HeLa cells were treated with the most active extracellular extract of Aspergillus sp. (Coded F-21-E) and doxorubicin as positive control at their $\mathrm{IC}_{50}$ value for $48 \mathrm{~h}$. The control, comprising cells without any treatment, served as blank. DMSO was used as the vehicle control. After treatment, cells were trypsinised and washed twice with PBS and then fixed with $70 \%$ ice cold ethanol in $-20{ }^{\circ} \mathrm{C}$ overnight. After completely removing the alcohol, the cells were spun down at $1200 \mathrm{rpm}$ for $5 \mathrm{~min}$ and washed with PBS. Cells were treated with PBS containing $50 \mu \mathrm{g} / \mathrm{mL}$ of RNase A for $3 \mathrm{~h}$ at $37^{\circ} \mathrm{C}$, mixed with $25 \mu \mathrm{g} / \mathrm{mL}$ of propidium iodide 
and analyzed by flow cytometry. Cells in different phases of the cell cycle were analyzed for both the controls and the cells treated with extracts (Dassonneville et al., 2000; Dengler et al., 1995).

\section{Preliminary chemical investigation}

Preliminary qualitative chemical analysis of various extracts of one promising isolate from each category (one bacterial and one fungal) was performed for the identification of various constituents of the extracts. All the analyses were carried out using 1-2 mL of extract solution. In the case of tests for carbohydrates, tests such as Molisch's, Fehling's, Benedict's, and Barfoed's tests were carried out. Tests for alkaloids (Dragendroff's, Mayer's, and Hager's tests), test for sterols (Liebermann Burchard test and Salkowsky test), tests for the detection of phenolic compounds and tannins, tests for proteins and free amino acids (Biuret test and Ninhydrin test) and also tests for the detection of flavonoids, were performed.

\section{Morphological studies and biochemical tests}

Morphological studies and biochemical tests of selected isolates were performed for partial characterization of the isolates and to test for any isolates present in repeats. In the case of bacterial isolates, Gram's Staining and Motility Studies (Hanging Drop Method) were carried out, while Lactophenol cotton blue staining was used to visualize the morphology of the fungal isolates (Tortora, 2005; Harley, 2002).

Biochemical Tests for selected isolates include $\mathrm{Ca}$ talase, Indole, Methyl Red and Voges Proskauer (MRVP), Citrate Utilization, Urease, Triple Sugar Iron Agar, Carbohydrate Utilization, Starch Utilization, Casein Utilization, Gelatin Liquefaction, EMB Agar. Mannitol Salt Agar, and SIM Medium tests were carried out (Harley, Prescott, 2002).

\section{RESULTS AND DISCUSSION}

\section{In vitro anticancer activity studies}

The effect of extracellular and intracellular extracts on the viability of cancer cells was determined by MTT (3-[4, 5-dimethylthiazol-2-yl]-2, 5-diphenyltetrazolium bromide) assay on HeLa cells. The most active extracts were further screened on MCF-7 cells by MTT assay. The $\mathrm{IC}_{50}$ doses were determined by exposing cells to various concentrations of the drugs ( 1000 to $10 \mu \mathrm{g} / \mathrm{mL}$ ) for $72 \mathrm{~h}$. The $\mathrm{IC}_{50}$ was defined as the concentration of drug at which there was 50\% less growth compared to control cells. Each experiment was performed in triplicate and is shown in the Tables I-III.

Results indicated that the chloroform extract of B-2C, ethyl acetate extracts of B-4E, and F-21E identified as Aspergillus sp. had promising anticancer activity against Cervical (HeLa) and Breast cancer (MCF-7) cell lines. B-2C at a concentration of $64.67 \pm 0.84 \mu \mathrm{g} / \mathrm{mL}$ showed $50 \%$ less growth compared to control on $\mathrm{HeLa}$ cells by the MTT method. B-4E showed a value of

TABLE I - Anticancer activity of bacterial extracts by MTT and SRB methods on HeLa cells

\begin{tabular}{lc}
\hline Working code & $\begin{array}{c}\mathrm{IC}_{50} \pm \mathrm{SEM}^{\mathrm{a}} \\
\text { by MTT method }(\mu \mathrm{g} / \mathrm{mL})\end{array}$ \\
\hline B2-P* & $>500$ \\
$\mathrm{~B} 2-\mathrm{C}$ & $64.67 \pm 0.84$ \\
$\mathrm{~B} 2-\mathrm{M}$ & $427.5 \pm 2.16$ \\
$\mathrm{~B} 4-\mathrm{E}$ & $106.82 \pm 1.19$ \\
B15-E & $463.2 \pm 2.39$ \\
Cisplatin & $6.58 \pm 0.81$ \\
Doxorubicin & $1.16 \pm 0.33$ \\
\hline
\end{tabular}

${ }^{\mathrm{a}}$ Average of three determinations.

* Extracts with $\mathrm{IC}_{50}$ greater than $500 \mu \mathrm{g} / \mathrm{mL}$ not shown

TABLE II - Anticancer activity of fungal extracts by MTT and SRB methods on HeLa cells

\begin{tabular}{lc}
\hline Working code & $\begin{array}{c}\mathrm{IC}_{50} \pm \mathrm{SEM}^{\mathrm{a}} \\
\text { by MTT method }(\mu \mathrm{g} / \mathrm{mL})\end{array}$ \\
\hline F6-E & $415.11 \pm 2.85$ \\
F12-M & $444.23 \pm 2.91$ \\
F13-P* & $>500$ \\
F13-E & $421.69 \pm 2.17$ \\
F13-M & $442.02 \pm 1.97$ \\
F14-P & $198.33 \pm 1.82$ \\
F14-E & $167.68 \pm 1.21$ \\
F14-C & $209.98 \pm 2.67$ \\
F15-P & $192.67 \pm 1.73$ \\
F15-E & $478.53 \pm 3.12$ \\
F15-C & $380.11 \pm 2.93$ \\
F19-P & $247.32 \pm 2.18$ \\
F19-E & $272.17 \pm 2.41$ \\
F19-C & $350.22 \pm 2.91$ \\
F19-M & $287.51 \pm 2.68$ \\
F21-P & $422.39 \pm 3.79$ \\
F21-E & $20.37 \pm 0.36$ \\
F21-C & $383.05 \pm 2.73$ \\
Cisplatin & $6.58 \pm 0.81$ \\
Doxorubicin & $1.16 \pm 0.33$ \\
\hline
\end{tabular}

${ }^{a}$ Average of three determinations.

* Extracts with $\mathrm{IC}_{50}$ greater than $500 \mu \mathrm{g} / \mathrm{mL}$ not shown 
TABLE III - Anticancer activity of extracts with promising isolates by MTT method on MCF-7 cell lines

\begin{tabular}{lc}
\hline Working code & $\begin{array}{c}\mathrm{IC}_{50} \pm \mathrm{SEM}^{\mathrm{a}} \\
\mu \mathrm{g} / \mathrm{mL}\end{array}$ \\
\hline F21-E & $44.75 \pm 0.81$ \\
B4-E & $178.65 \pm 1.02$ \\
B2-C & $197.34 \pm 0.94$ \\
Cisplatin & $10.01 \pm 0.46$ \\
\hline
\end{tabular}

${ }^{a}$ Average of three determinations.

$106.82 \pm 1.19 \mu \mathrm{g} / \mathrm{mL}$ and $\mathrm{F}-21 \mathrm{E}$ showed $\mathrm{IC}_{50}$ of $20.37 \pm 0.36$ $\mu \mathrm{g} / \mathrm{mL}$, which were compared with cisplatin with an $\mathrm{IC}_{50}$ of $6.58 \pm 0.81 \mu \mathrm{g} / \mathrm{mL}$. B-2C at a concentration of $197.34 \pm 0.94 \mu \mathrm{g} / \mathrm{mL}$ showed $50 \%$ less growth compared to control on MCF-7 cells by the MTT method, B4-E showed a value of $178.65 \pm 1.02 \mu \mathrm{g} / \mathrm{mL}$ and F-21E showed $\mathrm{IC}_{50}$ of $44.75 \pm 0.81 \mu \mathrm{g} / \mathrm{mL}$, which were compared with cisplatin with an $\mathrm{IC}_{50}$ of $10.01 \pm 0.46 \mu \mathrm{g} / \mathrm{mL}$ (Table-III).

Additionally, extracts from other isolates viz., F14P, F-14E, F-14C,F-15P and F-19P showed an $\mathrm{IC}_{50}$ of $125-250 \mu \mathrm{g} / \mathrm{mL}$ and B-2M, B-15E, F-6E, F-12M, F-13C, F-13M, F-15E, F-15C, F-19C, F-19E, F-19M, F-21P and F-12C showed $\mathrm{IC}_{50}$ between $250-500 \mu \mathrm{g} / \mathrm{mL}$ by MTT on HeLa.

Based on the results of in vitro anticancer studies of all extracellular and intracellular extracts, two highly active extracts were selected for Hoechst 33342 staining to study the compound mediated apoptosis. The whole process of programmed cell death could be divided into three morphological distinct stages. Condensation of chromatin of nuclear segments (Karyopyknosis) and their fusion into single spherical structures were observed during early apoptosis. The second stage zeiosis was characterized by progressive blebbing of cytoplasmic membrane and disruption of phyknotic nucleus into several small spherical fragments. In the third stage, the disruption resulted in formation of apoptotic bodies. When stained with a nuclear fluorochrome Hoechst 33342, the normal (untreated control) HeLa cells remained uniformly stained with rounded and unpunctuated nucleus (Figure 1). HeLa cells treated with cisplatin showed nuclear fragmentation, shrinkage of cell nucleus, with condensation of the chromatin (karyopyknosis) (Figure 2), which were the characteristic features of apoptotic morphology. The two extracts selected for the study showed some characteristic features of apoptosis. Morphological characteristics include nuclear fragmentation, fragmentation into apoptotic bodies, karyopyknosis and zeiosis (membrane blebbing seen frequently in a dying cell) (Figures 3 and 4). These observations provide eviden-

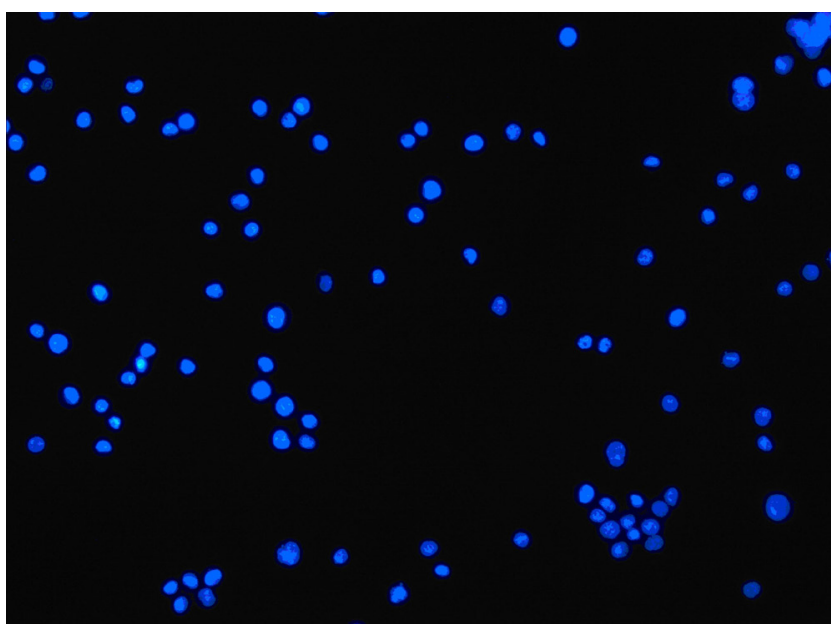

FIGURE 1 - Normal (Control) HeLa cells uniformly stained with rounded and unpunctuated nucleus showing no signs of necrosis or apoptosis.

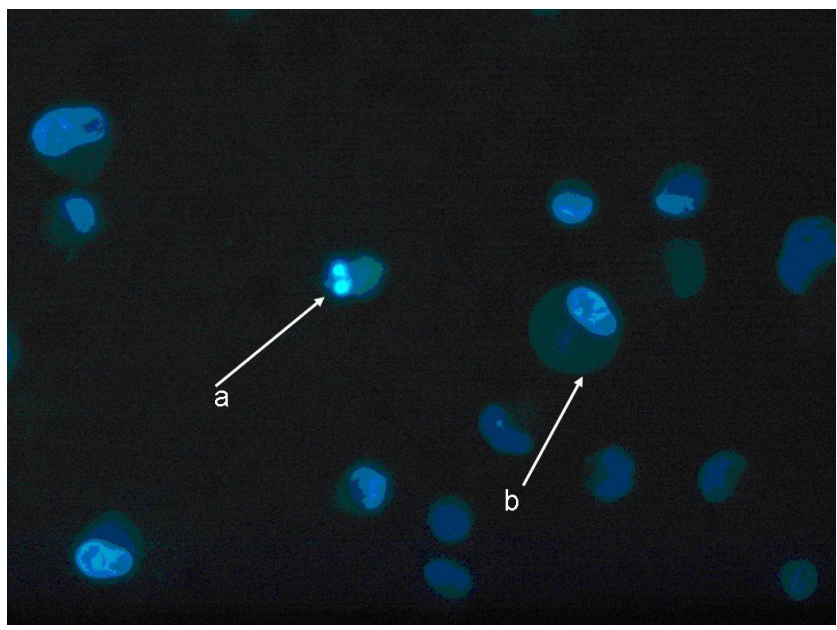

FIGURE 2 - Effect of cisplatin on HeLa cells, showing: a) Nuclear fragmentation; b) Karyopyknosis (shrinkage of a cell nucleus, with condensation of the chromatin).

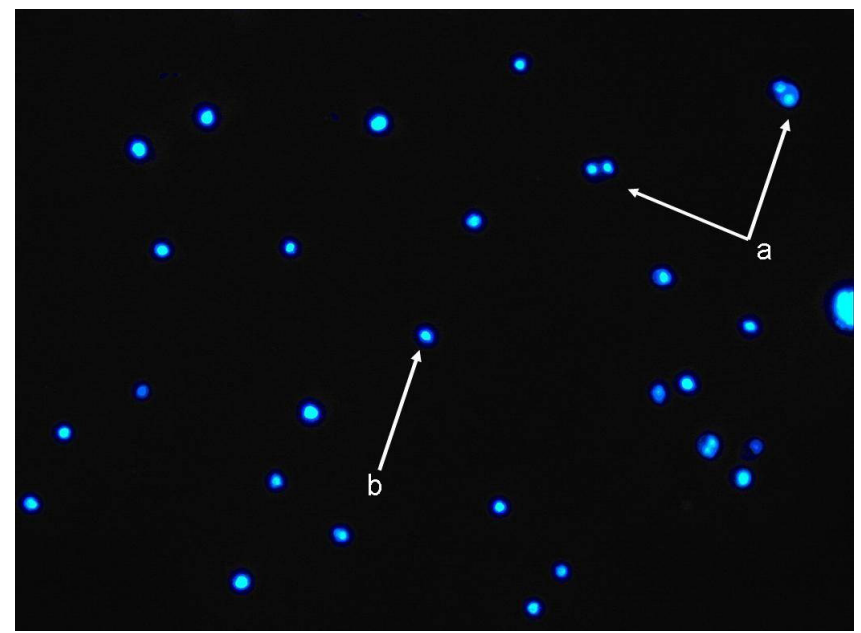

FIGURE 3 - Effect of B-2C on HeLa cells showing: a) Nuclear fragmentation; b) Karyopyknosis. 


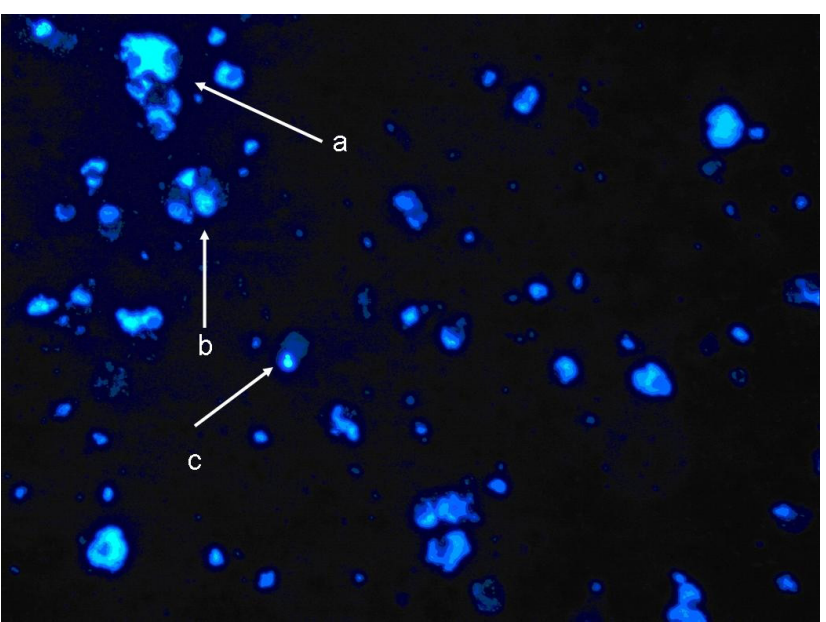

FIGURE 4 - Effect of F-21E on HeLa cells showing: a) Zeiosis (membrane blebbing seen frequently in a dying cell) Nuclear fragmentation; b) Fragmentation into apoptotic bodies; c) Karyopyknosis - shrinkage of a cell nucleus, with condensation of the chromatin.

ce that an anoikis (form of programmed cell death which is induced by anchorage-dependent cells detaching from the surrounding extracellular matrix) occurred when HeLa cells were treated with test extracts selected for the study.

The cell cycle analysis revealed that the proportion of cells in the $\mathrm{G}_{2} / \mathrm{M}$ phase that had been treated with doxorubicin for $48 \mathrm{~h}$ was $76.76 \%$. The untreated group yielded only $18.65 \%$ after $48 \mathrm{~h}$ (Figures 5 and 6). This indicated that doxorubicin induced cell cycle arrest at the $\mathrm{G}_{2} / \mathrm{M}$ phase.

As shown in Figure 7, the ethyl acetate extract of $\mathrm{F}$ 21- E (Aspergillus sp) induced an accumulation of cells

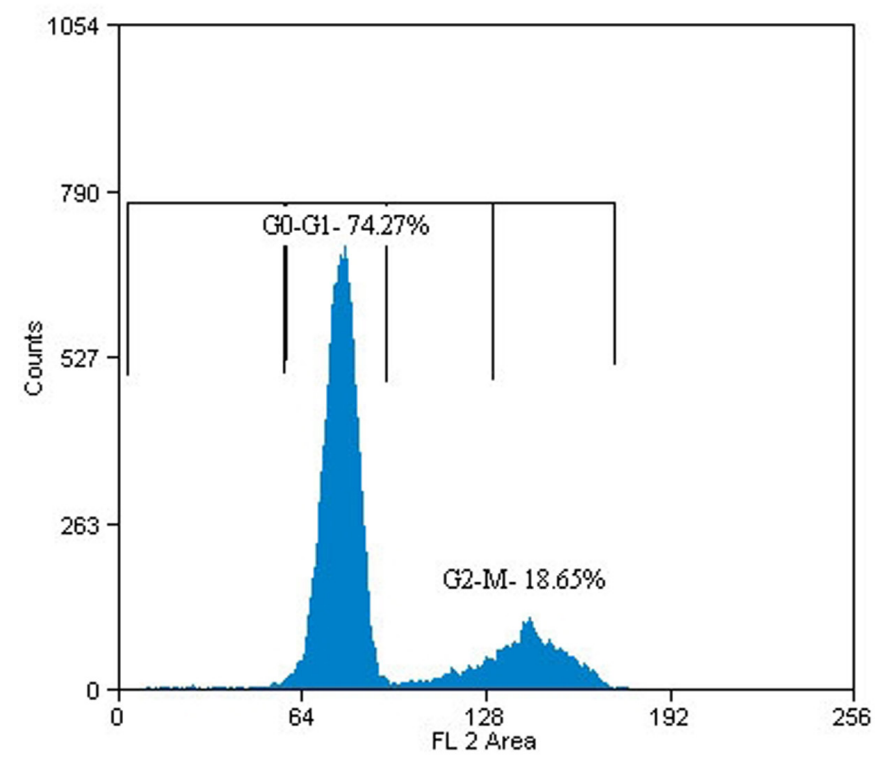

FIGURE 5 - Control HeLa cells showing normal cell cycle.

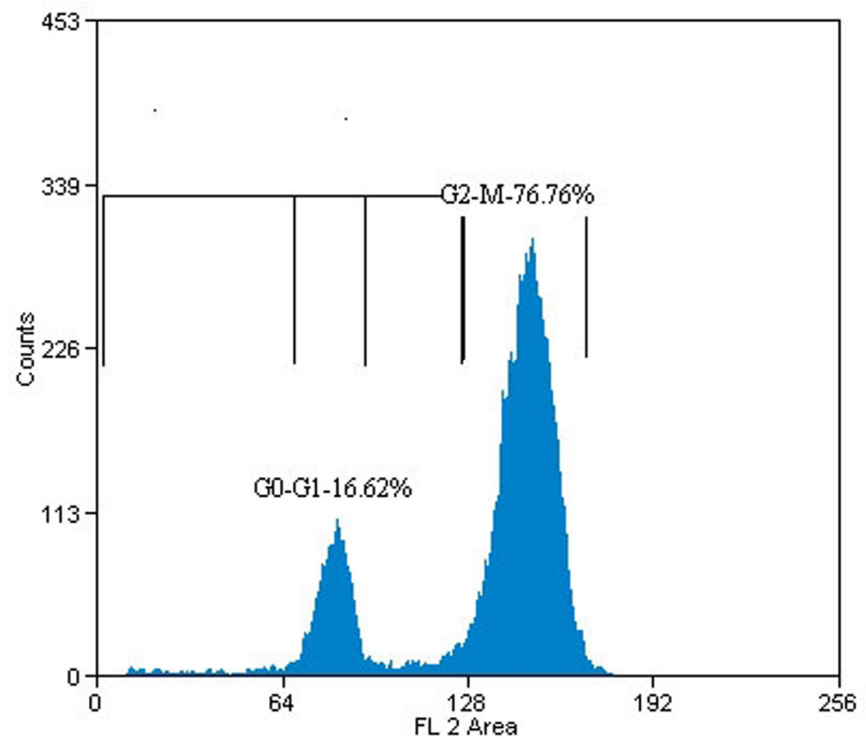

FIGURE 6 - Doxorubicin showing prominent $\mathrm{G}_{2}-\mathrm{M}$ phase arrest.

in the Sub- $\mathrm{G}_{0}$ phase $(90.92 \%)$ compared to that in the untreated cells (1.15\%), indicating that F 21- E extensively triggered apoptosis at the dose used $\left(\mathrm{IC}_{50}\right)$. The chloroform extract of B2 showed cell cycle arrest at the Sub $\mathrm{G}_{0}$ phase (18.62\% versus $1.15 \%$ of control). In the $S$ phase, $16.09 \%$ of cells were found versus $6.34 \%$ of control. Also in $\mathrm{G}_{2}$ -M phase was $28.11 \%$ versus $18.65 \%$ of control, shown in Figure 8.

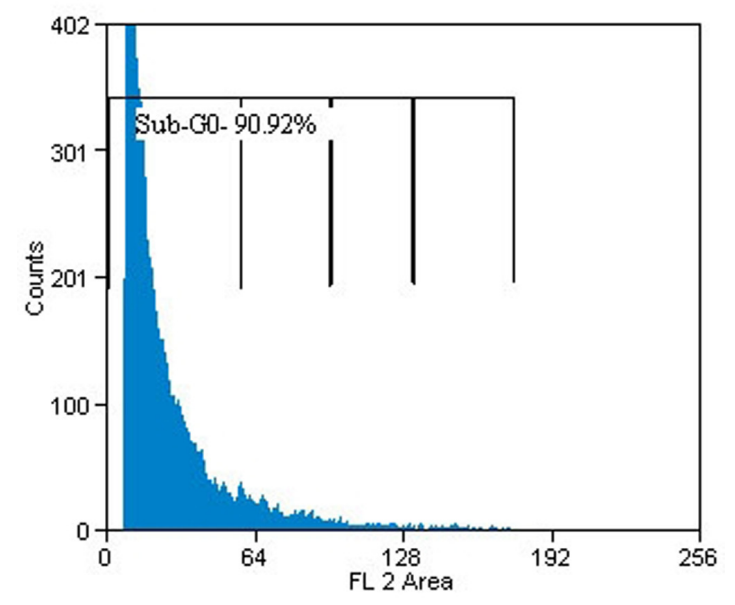

FIGURE 7 - F-21 E treated HeLa cells showing cell accumulation in sub $\mathrm{G}_{0}$ phase.

The chloroform extract of B2 showed increased cell population in both the Sub- $\mathrm{G}_{0}$ phase and $\mathrm{G}_{2} / \mathrm{M}$ phase compared to the control cells, indicating that B-2C causes both apoptotic and $\mathrm{G}_{2} / \mathrm{M}$ phase arrest (Figure 8 ). Entry into each phase of the cell-cycle is carefully regulated by receptor collectives, termed cell-cycle checkpoints. 


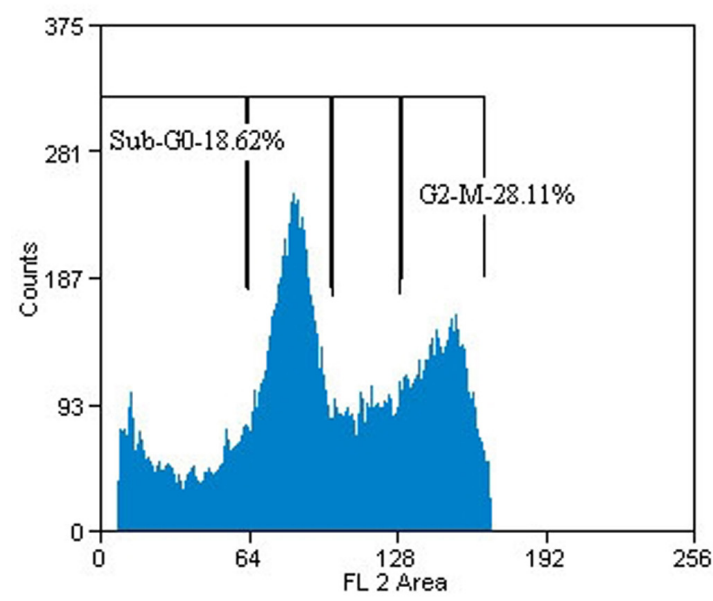

FIGURE 8 - B-2C treated HeLa cells showing sub $\mathrm{G}_{0}$ (apoptotic) and $\mathrm{G}_{2}-\mathrm{M}$.arrest.

The $\mathrm{G}_{2} / \mathrm{M}$ checkpoint prevents DNA-damaged cells from entering mitosis and allows for the repair of DNA that was damaged in late $\mathrm{S}$ or $\mathrm{G} 2$ phases prior to mitosis. The $\mathrm{G}_{2} / \mathrm{M}$ checkpoint is controlled by $\mathrm{Cdc} 2 /$ cyclinB. Active $\mathrm{Cdk} 1(\mathrm{cdc} 2)$ complexed to cyclin B1 is required for progression from the $\mathrm{G}_{2}$ to $\mathrm{M}$ phase. Regulation of the cdc2-B1 complex involves inhibitory phosphates at a pair of amino acids in the roof of the active site by Weel. Dephosphorylation of these sites by the phosphatase Cdc25C increases Cdk activity. DNA damage activates Chk1, which inactivates Cdc25C through phosphorylation of $\operatorname{cdc} 25 \mathrm{C}$, resulting in the phosphorylation and inactivity of cdc2-B1 and $\mathrm{G}_{2}-\mathrm{M}$ arrest. Weakened $\mathrm{G}_{2} / \mathrm{M}$ checkpoint under a therapeutic setting may trigger cell death via mitotic catastrophe for cells with unrepairable DNA lesions and mitosis machinery. These results suggest that DNA damage in the cells caused by B-2C may be irreparable and therefore force the arrested cells into apoptosis. Thus, B-2C-induced DNA damage may be attributed due to the activation of Chk2 and decline in the expression of $\mathrm{Cdc} 25 \mathrm{C}$ and $\mathrm{Cdc}-2$, which leads to $\mathrm{G}_{2} / \mathrm{M}$ arrest and eventually, apoptosis.

\section{Preliminary chemical investigation}

Chloroform and petroleum ether extract of B-2 indicated the presence of only sterols, while the ethyl acetate extract indicated the presence of flavonoids along with sterols whereas methanolic intracellular extract showed the presence of alkaloids, carbohydrates, phenolic compounds, proteins and amino acids. The anticancer activity of B-2 C may be attributed due to the presence of sterols (Table IV) (Angel, 2008).

In the case of F-21, the ethyl acetate extract showed the presence of only sterols. Hence the anticancer activity may be due to the presence of sterols. Sterols were also found in petroleum ether and chloroform fractions. The methanolic extract indicated the presence of various chemical constituents viz., carbohydrates, tannins, phenolic compounds, proteins, amino acids and flavonoids (Table V).

TABLE IV - Qualitative preliminary chemical investigation of various extracts of an active bacterial isolate B-2 (Bacillus sp.)

\begin{tabular}{lcccccc}
\hline Nature of Extracts & Alkaloids & Carbohydrates & Sterols & $\begin{array}{c}\text { Tannins \& } \\
\text { phenolic } \\
\text { compounds }\end{array}$ & $\begin{array}{c}\text { Proteins \& } \\
\text { amino acids }\end{array}$ & Flavonoids \\
\hline Pet. Ether (B2-P) & - & - & + & - & - & - \\
Ethylacetate (B2-E) & - & - & + & - & - & + \\
Chloroform (B2-C) & - & - & + & - & - & - \\
Methanol (B2-M) & + & + & - & + & + & - \\
\hline
\end{tabular}

TABLE V - Qualitative preliminary chemical investigation of various extracts of the active fungal isolate F-21 (Aspergillus sp.)

\begin{tabular}{lcccccc}
\hline Nature of Extracts & Alkaloids & Carbohydrates & Sterols & $\begin{array}{c}\text { Tannins \& } \\
\text { phenolic } \\
\text { compounds }\end{array}$ & $\begin{array}{c}\text { Proteins \& } \\
\text { amino acids }\end{array}$ & Flavonoids \\
\hline Pet. Ether (F21-P) & - & - & + & - & - & - \\
Ethylacetate (F21-E) & - & - & + & - & - & - \\
Chloroform (F21-C) & - & - & + & - & - & - \\
Methanol (F21-M) & - & + & + & + & + & + \\
\hline
\end{tabular}




\section{CONCLUSION}

Extracellular as well as intracellular extracts of the metabolites of thirty-six bacterial and twenty-four fungal isolates, grown under unusual conditions such as high temperature, high sodium chloride and low glucose concentrations, were in vitro tested for their cytotoxic potential on various cancer cell lines. The extracts were screened on HeLa and MCF-7 cell lines to study cytotoxic potential. The crude ethylacetate extract of isolate F-21 showed promising results by MTT assay with $\mathrm{IC}_{50}$ as low as $20.37 \pm 0.36 \mu \mathrm{g} / \mathrm{mL}$ on HeLa, and $44.75 \pm 0.81 \mu \mathrm{g} / \mathrm{mL}$ on MCF-7 cells, comparable with Cisplatin. The isolate F-21 was identified as Aspergillus sp. Promising results were obtained with B-2C and B-4E. Hoechst 33342 staining of HeLa cells treated with F-21E and B-2C extracts, in comparison with positive and negative controls, revealed that cytotoxicity is due to apoptosis as well as cell necrosis. Flow-cytometric analysis indicated that the extracts of F-21E and B-2C extensively triggered apoptosis, evident from the accumulation of cells in the Sub- $\mathrm{G}_{0}$ phase compared to that of control. Further studies can be carried out on bioassay-guided fractionation of the active extract for the isolation of active constituent, structural elucidation of the active constituent, systematic taxonomical studies for characterization of the isolates, optimization of production parameters, and also on scaling up of the process.

\section{ACKNOWLEDGEMENT}

The authors wish to acknowledge the authorities of Manipal University, Manipal, Department of Science and Technology, New Delhi and the All India Council for Technical Education, New Delhi for providing the necessary infrastructure and financial support for carrying out this study.

\section{REFERENCES}

ANGEL, T.T. Bioprospecting: biological activity profile of microbial isolates from aqua to terrestrial sources. Manipal, India, 2008. p.1-109. [M. Pharm Thesis, Manipal University].

ANGEL, T.T.; VENKATA RAO, J.; JESIL M..A.; SUBRAHMANYAM, V.M.; VENKATESH K.B.; UDUPA, $\mathrm{N}$. Antimicrobial profile of extremophiles from aqua to terrestrial habitats. Pharmacologyonline, v.1, p.111-126, 2009.
ATTA-UR-RAHMAN.; IQBAL, C.E.; WILLIAM, J.T. Bioassay techniques for drug development. Amsterdam: Harwood Academic Publishers, 2001. p.1-5.

BABICH, H.; KRUPKA, M E.; NISSIM, H.A.; ZUCKERBRAUN, H.L. Differential in vitro cytotoxicity of (-) Epicatechin gallate (ECG) to cancer and normal cells from the human oral cavity. Toxicol. in Vitro, v.19, p.231242, 2005.

BUKHARIN, O.V.; SGIBNEV, A.V.; CHERKASOV, S.V.; IVANOV, Y.U. B. The effect of the intra - and extracellular metabolites of microorganisms isolated from various ecotopes on the catalase activity of Staphylococcus aureus ATCC 6538 P. Microbiology, v.71, p.154-157, 2002.

BUTLER, M.S. Natural products to drugs: natural products derived compounds in clinical trials. Nat. Prod. Rep., v.25, p.475-516, 2008.

CLARDY. J. Discovery of new compounds in nature. Proc. Amer. Phil. Soc., v.151, p.201-210, 2007.

DASSONNEVILLE, L.; LANSIAUX, A.; WATTELET, A.; WATTEZ, N.; VAN MIERT, S.; BAILLY, C. Cytotoxicity and cell cycle effects of the plant alkaloids cryptolepine and neocryptolepine: relation to drug-induced apoptosis. Eur. $J$. Pharm., v.409, p.9-18, 2000.

DENGLER, R.; MUUNSTERMANN, U.; AL-BATRAN, S.; HAUSNER, I.; FADERL, S.N.C.; EMMERICH. B. Immunocytochemical and flow cytometric detection of proteinase 3 (myeloblastin) in normal and leukaemic myeloid cells. Brit. J. Haem., v.89, p.250-257, 1995.

EISENBRAND, G.; POOL, Z.; BAKER, V.; BALLS, M.; BALAAUBOER, B.J. Methods of in vitro toxicology. Food Chem. Toxicol., v.40, p.193-236, 2002.

FIEDLER, H.P. Screening for bioactivity. In: BULL, A.T. (Ed.). Microbial diversity and bioprospecting. Washington DC: ASM Press, 2004. p.324-335.

HARLEY, J.P.; PRESCOTT, L.M. Laboratory exercises in microbiology. 5.ed. Columbus: The MC Graw Hill Companies, 2002. p.13-16, 125-207.

JEFFREY, M.E.; LINDA, S.A.; ANDREW, O.M. A rapid and simple MTT based spectrophotometric assay for determining drug sensitivity in monolayer culture. Tissue Cult. Meth., v.11, p.15-17, 1998. 
LENE, L. Microbial metabolites-an infinite source of novel chemistry. Pure Appl.Chem., v.68, p.745-748, 1996.

MARIANNA, J.; JAMES, P.K.; RONALD, R.R. Macquarimicins, microbial metabolites from Micromonospora I. Discovery, taxonomy, fermentation and biological properties. $J$. Antibiot., v.48, p.462-466, 1995.

NEWMAN, D.J.; CRAGG, G.M.; SNADER, K.M. Natural products as sources of new drugs over the period 19812002. J. Nat. Prod., v.66, p.1022-1037, 2003.

NEWMAN, D.J.; CRAGG, G.M.; SNADER, K.M. The influence of natural products upon drug discovery. Nat. Prod. Rep., v.17, p.215-234, 2000.

RUBINSTEIN, L.V, SHOEMAKER, R.H.; PAULL, K.D.; SINON, R.M.; TOSINI, S.; SKEHAN, P.; SCUDIERO, A.M.; BOYD, M.R. Comparison of in vitro anticancer drug screening data generated with tetrazolium assay versus a protein assay against a diverse panel of human tumor cell lines. J. Nat. Cancer Inst., v.82, p.1113-1117, 1990.
KIM, S. N.; WON, G.K.; HYE, J.J.; JOONG, S.S.; HYE, J.K.; HYANG, B.L.; JAE, T.H. CHANG, J.K.; NAM, I..B.; ICK, D.Y.; HO, J. K. Cell cycle inhibitory activity of 4-hydroxy3-(3-methyl-2-butenyl)-benzoic acid from Curvularia sp. KF119. J. Antibiot., v. 57, p.605-608, 2004.

SNEADER, W. Drug discovery: a history. Hoboken, NJ: John Wiley \& Sons, 2005. p.969-982.

TORTORA, G.J.; FUNKE, B.R.; CASE, C,L. Microbiology - an introduction. 8. ed. Singapore: Pearson Education, 2005. p.97-99, 112-115.

YAO, D.; LI, H.; GOU, Y.; ZHANG, H.; VLESSIDIS, A,G.; ZHOU, H.; EVMIRIDIS, N.P.; LIU, Z. Betulinic acid-mediated inhibitory effect on hepatitis $B$ virus by suppression of manganese superoxide dismutase expression. FEBS Lett., v. 276, p.2599-2614, 2009.

Received for publication on $14^{\text {th }}$ May 2010. Accepted for publication on $14^{\text {th }}$ July 2010. 